\title{
A Case Study of the Relationship between Seniors' EFL Attitudes and Their Employment Intentions
}

\author{
Daoshan Ma \\ School of Foreign Languages, Tianjin Polytechnic University, Tianjin City, China
}

\begin{abstract}
In this thesis, seniors from six universities are investigated on the relationship between EFL attitudes and their employment intentions. Data are collected through questionnaires and analyzed in general which shows that they hold comparatively negative attitudes toward the relationship between CET (College English Test) and their employment intentions.
\end{abstract}

Index Terms - attitude, employment intention, interaction, College English Test

\section{INTRODUCTION}

S. Rosenberg and C. I. Hovland (2003) hold a very influential view that attitude consists of three aspects, namely, cognition, emotion, and behavior tendency. This point of view has been widely approbated by most social psychologists. Generally speaking, the cognitive element of the attitude is considered as a statement of judgments, not exclusive of the understanding and comprehension of the attitudinal objective. According to their analysis, emotion can be understood as emotional experience of the attitude towards the attitudinal objective, such as favor, averseness, sympathy and sneer. Meanwhile, behavior tendency is termed to be a kind of internal response, which is a prepared state kept by a person before acting. For the purpose of attitude measuring, it appears to be very clear that emotion index will be more effective and convenient to use than other indexes. Scholars believe that English study is influenced by the interaction of cognition and emotion. (Chang, Kang \& Wang, 2005, p.730)

According to the research purpose and characteristics of the investigative objective, the author makes some assumptions as follows:

1. Having already passed the CET band four, the students hold more active attitudes to the College English Test.

2. The undergraduates pay much more attention to the practicability of language, such as oral English, which is beneficial to hunting a job.

3. The seniors' learning of a foreign language appears to show diversity tendency, but it is not just confined to English.

4. College English Test achievement is an influential factor which plays a crucial role in their employment intention for most seniors.

It is expected that some discovery from the investigation can be found to test these hypotheses.

\section{LITERATURE REVIEW}

There are many researches about English learners' motivation and they have gained some insights and made some achievements. For example, some scholar considers that the college students take the College English Test with a clear tendency of utilitarian purposes. (Ma, 2005: 259) The hard work in English learning done by most Chinese university students is not that they have a very strong motive of learning, but that they have to adapt themselves to the social demands. (Huang \& Wen, 2005: 34) The function of CET is limited in evaluating the present quality of English teaching in some Chinese universities. (Tang, 2005: 59) The current test lacks of reliability and validity, which is performed in one aspect as devoid of testing for social communicative ability. (Wang, 2005: 52) In recent years, employers are dissatisfied with the university student's comprehensive ability of English. Basically, the students are just guided by CET without paying attention to developing their communicative competence. (Tang, 2005: 65)

Moreover, some researchers have made some investigations on such an issue from the perspective of psychology. A program which is especially directed by Gao Yihong (2004: foreword), did multi-angular and systematical study on the motivation and the self-identification of Chinese university English learners. The achievement is convincing because of the professional rigorous and scientific approach.to the research.

Obviously, among those researches, college students' attitude to CET has not been well studied. Due to some limitations, the author has not found much data in this field.

\section{RESEARCH METHOD}


Questionnaire is in common use for multifarious investigations because it's handy and convenient to be controlled. For those advantages the author also chooses this method to accomplish the investigation.

\section{A. Research Objective}

This research is merely conducted among a small crowd. As a special colony, senior students have to face job-hunting after graduation. But previous researches are generally aimed at an investigation on the freshmen and sophomores or third year students. Hence, the objective of this thesis is aimed at seniors from non-English majors who have passed the written-examination of CET. Those who have not passed the test are not to be chosen for the reason that their attitudes are not to be affected by the pressure.

\section{B. Process of Research}

The questionnaire is a descriptive one, compiled and made up of three parts with 31 questions. The first part is composed of some basic information about the student and his or her English level. The second part, which adopts the method of Likert scale, is made of single choice questions with 20 declarative sentences which should be chosen from five options to best express the student's attitude. The last part is multinomial choice with 6 questions.

46 questionnaires are handed out to some senior students in six main universities in Tianjin, which are Nankai University, Tianjin Polytechnic University, Tianjin University, Tianjin Medical University, Tianjin Normal University, and Tianjin Commercial University, and 41 questionnaires are valid with a rate of $89 \%$. Among the subjects, there are 23 male students from different universities, and 18 female students, who are from 14 different majors of liberal arts, science, medicine, and art etc.

There are many influential factors which are involved in the formation of one's attitude, so some of those factors need to be controlled in certain context. And with the imbalanced development of Chinese economy and education, there are some differences in people's command of English language in different regions. To make the result more typical and to limit the influence of regional difference, the author chooses students who come from different regions of the north and the south in China. Besides, gender ratio, major of the students and representatives of the universities are all considered. Since the questionnaire is to describe the seniors' attitudes towards College English Test but not to be used as research tools, the data collected was not processed for complicated statistical analysis.

\section{DATA ANALYSiS}

The scoring method of the questionnaire is that for questions 1, 4, 5, 6, 8, 9, 10 in Section Two the choice of A to $\mathrm{E}$ scores 5 to 1 point respectively, and for other questions, the choice of A to E scores 1 to 5 points respectively. The highest score is 75 points, the lowest is 15 points, and in the middle is 40 points. From the results we can see that the highest score the students achieve is 49 points and the lowest score the students achieve is 26 points. The number of the students who achieve more than 40 points is 24 , among which there are 12 females. This shows that the total score the subjects have achieved is generally low. Although some of them have passed CET-4, and half of them have passed CET-6, their evaluation of CET-4 and CET-6 is not very high. Therefore we can see that hypothesis one does not stand right and hypothesis 2 and hypothesis 3 are proven to be correct from the results of Section Two and Section Three. From the statistical data, it appears that some problems for university students do exist in English learning.

From the holistic low score of attitude investigation, as we have just mentioned in the above paragraph, clearly, it can be said that the subjects being chosen prevalently hold a little bit negative attitude to College English Test. Though all of the students investigated have already passed written examination of CET, the seniors did not give a high evaluation to College English Test. Some reasons can be found in the collected data. To analyze the data concretely, the students doubt that the content of College English Test is useful for them. How could they give high appraisal to something that they consider to be useless to them?

Although many students think that CET can estimate a student's mastery of the College English course, fewer students admit that College English Test can really reflect how well it is mastered. The result of items 4 and 5 seems to be antinomic; actually the phenomenon reflects the students' disaffection to College English teaching, because College English Test is not actually following the university English teaching syllabus. Data of items 13 and 15 corroborates that the analysis above is right, and that most students do not feel that they have made obvious progress in the College English course.

Items 8 and 9 show that the seniors are generally affirmative to the importance of CET school reports, but the achievement of CET is not the main factor in their choice to go abroad or enter a foreign company. Whether they go abroad or hunt a job in the overseas-funded enterprise or not is not closely related with the results of CET.

From item 11, most of the students think greatly of mastering professional knowledge and skills, certainly including the study of the professional English. However, there are still over two-fifths of the seniors who figure that the current English teaching can't satisfy their needs of learning professional knowledge in English. Universities arrange professional English course to cultivate students' catena reading ability and prepare themselves for their further scientific research, but since many of the teachers for those courses know little about the law of foreign language teaching, it turns out to be, unfortunately, another intensive reading lesson. (Liu \& Dai, 2003: 99)

Generally speaking, people think girls are good at learning a foreign language, but job-hunting is much more difficult 
for them compared with boys. That's one of the reasons for nearly half of the seniors who consider that the ability to master English is much more important for girls.

Many students deem that CET school reports should not be so emphasized by employers because they cannot represent all of the students' capacity. The ability of using the language should be more important than CET school reports.

Most of the people look forward to a decent job which could offer them a considerable amount of pay. Based on this expectation, the undergraduates prefer to find opportunity in enterprises wholly-invested by foreigners, and Chinese-foreign joint ventures. Meanwhile, no matter where they come from, the seniors prevalently want to work at open coastal cities, which are the most developed regions of Chinese economy. Nearly all the overseas-funded enterprises and the joint ventures will require the newly graduates of some proficient English. From the research data it can be seen that this viewpoint is accepted undoubtedly by a majority of the seniors. This might be one of the motives why they want to learn English well at the universities before they are graduated.

Most of the seniors know clearly about their weaknesses in English learning. Even for those who have passed CET, speaking English and using it in everyday life is not as easy as getting a high mark in the written test. That's why as many as $76 \%$ of the seniors long for improving their oral English at present, and 51\% for improving their listening comprehension. In addition, reading comprehension, writing and translation are also needed to be reinforced, although these are exactly what College English Test tests the students.

Most of the seniors have not taken part in other English tests. On one hand, it can prove how important CET is viewed by university students. On the other hand, it can be explained that the students' recognition of the importance of CET is due to a direct relationship between a CET school report and a desirable job. This fact is not in conformity with what the students wish to be, who think that the ability to use English should be considered as that of more significance than the school reports of CET.

While facing a significant option in their lives, two-thirds of the students choose to go for further study. We can see that what the seniors intend to get is still a satisfied job. It's somewhat surprising that a plurality of the seniors do not want to hunt a job related to what they have learned at university. This shows that the majors that the students choose at the universities are not what they consider as of some importance in the factors of hunting a job. And meanwhile it may also display that what the students learn at the universities is not what they need in their future careers.

From the data of the questionnaire it shows a comparatively high coherence. So this investigation basically achieves the expected purpose.

The current College English Test lacks the test of specific social communicative skills, which makes CET invalid. Some scholars indicate that the current syllabus just regulate a certain quantity of vocabulary, while, other content is ambiguous, which could not offer an ideal theoretical structure for testing. (Ren, 2005: 261)Consequently, the syllabus can not guide College English Test.

The reform of College English Test signals evidently that as popularization of English in higher educational institutions, the focal point of English teaching will turn to professional English gradually. Only in this way can professional trait of different universities incarnated, thus the undergraduates can accommodate themselves to the current social requirements. (Ren, 2005: 261)

From all the analyses in this thesis, the conclusion can be drawn as follows: even though they have passed the CET, the seniors are not satisfied with it, because a CET report card is an auxiliary for seniors to apply for a desirable job, but not an influential or decisive factor in their job-hunting.

\section{LiMITATIONS}

Because of limited time and lack of data for reference, the investigated items in the questionnaire are a little scattered and need to be perfected. Another problem is that the questionnaires are all handed out by seniors, so students investigated might not be serious enough in their choices. There might also be some misunderstandings on the same item for different students, which will interfere with the subjects in making their choices.

If there are some voices from the employers, it would be more persuading.

Though the investigated subjects are various and comparatively typical, the quantity of investigation is not big enough. It is still worth doing further researches in the future.

\section{APPENDIX. QUESTIONNAIRE}

Dear friend,

Hi. This questionnaire is designed to make a survey on your attitude towards CET-4 and CET-6. Please answer the following questions carefully and express what you really feel about the test according to the following requirements. This will take you some of your precious time and we are grateful to your help.

Part One: Background information.

Please write your corresponding information on the line or put a tick on the line.

I am ___ male or ___emale.

I am/have been graduated from University. 
My major is

I am from (Province or city).

I have passed ___ CET-4 or ___ CET-6 or __ both.

Part Two: Please choose one item that best expresses your opinion and click the corresponding letter marked with A, $\mathrm{B}, \mathrm{C}, \mathrm{D}$ or E.

1. I think that excellent achievements of the CET-4 and CET-6 may prove that my ability of learning is remarkable, and poor performance may show that my ability of learning is also poor.
A. I agree with it very much.
B. I agree with it.
C. I don't know.
D. I don't agree.
E. I don't agree with it at all.

2. I think the practical ability of using English language is more important than the results of the CET-4 and CET-6.
A. I agree with it very much.
B. I agree with it.
C. I don't know.
D. I don't agree.
E. I don't agree with it at all.

3. I think that what CET-4 and CET-6 test us is not very practical.
A. I agree with it very much.
B. I agree with it.
C. I don't know.
D. I don't agree.
E. I don't agree with it at all.

4. I think that CET-4 and CET-6 can test out my level of learning in College English course.
A. I agree with it very much.
B. I agree with it.
C. I don't know.
D. I don't agree.
E. I don't agree with it at all.

5. I think that the results of CET-4 and CET-6 may show the actual performance of my English language learning.
A. I agree with it very much.
B. I agree with it.
C. I don't know.
D. I don't agree.
E. I don't agree with it at all.

6. I think that the changes that have taken place in the reform of CET-4 and CET-6 have made great progress in testing a foreign language.
A. I agree with it very much.
B. I agree with it.
C. I don't know.
D. I don't agree.
E. I don't agree with it at all.

7. I think that the school report of CET-4 and CET-6 by issuing a report card instead of the original certificates does nothing but reduces the importance of the test itself.
A. I agree with it very much.
B. I agree with it.
C. I don't know.
D. I don't agree.
E. I don't agree with it at all.

8. I think that the school report of CET-4 and CET-6 is a first step forward to the success of hunting a job.
A. I agree with it very much.
B. I agree with it.
C. I don't know.
D. I don't agree.
E. I don't agree with it at all.

9. After I have passed the tests, I am considering of the possibility of going abroad for further studies or entering an overseas-funded enterprise to work.
A. I agree with it very much.
B. I agree with it.
C. I don't know.
D. I don't agree.
E. I don't agree with it at all.

10. I think that the school report of CET-4 and CET-6 is much more reasonable than the certificates of qualification.
A. I agree with it very much.
B. I agree with it.
C. I don't know.
D. I don't agree.
E. I don't agree with it at all.

11. I think that professional skills and knowledge are more important than the grades of CET-4 and CET-6.
A. I agree with it very much.
B. I agree with it.
C. I don't know.
D. I don't agree.
E. I don't agree with it at all.

12. I think that the textbooks of College English are far more different in contents from what CET-4 and CET- 6 test us.
A. I agree with it very much.
B. I agree with it.
C. I don't know.
D. I don't agree.
E. I don't agree with it at all.

13. I think that the courses of College English have been proven to be of limited use.
A. I agree with it very much.
B. I agree with it.
C. I don't know.
D. I don't agree.
E. I don't agree with it at all.

14. I think that I have learned nearly nothing of use in the course of professional English for non-English majors.
A. I agree with it very much.
B. I agree with it.
C. I don't know.
D. I don't agree.
E. I don't agree with it at all.

15. I think that the courses should be designed to include more for the students' practical needs in the future.
A. I agree with it very much.
B. I agree with it.
C. I don't know.
D. I don't agree.
E. I don't agree with it at all.

16. I think that the original CET-4 and CET-6 certificates are of more importance to me than the present school reports.
A. I agree with it very much.
B. I agree with it.
C. I don't know.
D. I don't agree.
E. I don't agree with it at all.

17. I think that the results of the CET-4 and CET-6 are closely related with the teacher's performance. 

A. I agree with it very much.
B. I agree with it.
C. I don't know.
D. I don't agree.
E. I don't agree with it at all.

18. I think that professional English for non-English majors is quite necessary.
A. I agree with it very much.
B. I agree with it.
C. I don't know.
D. I don't agree.
E. I don't agree with it at all.

19. I think that it is more difficult to improve my writing than my speaking in English.
A. I agree with it very much.
B. I agree with it.
C. I don't know.
D. I don't agree.
E. I don't agree with it at all.

20. I think it is very difficult for me to improve my speaking in English.
A. I agree with it very much.
B. I agree with it.
C. I don't know.
D. I don't agree.
E. I don't agree with it at all.

Section Three

Please choose on or more items that most suits to your opinion, you may tick the corresponding letter marked with A, B, C, D.

1. What do you plan to do after your graduation?
A. For further studies
B. Joining the work force.
C. Going abroad.
D. Other choices.

2. What courses have you attended before?
A. The training courses for CET-4 and CET-6.
C. TOEFL
D. IELTS
E. GRE
B. The training courses for postgraduate entrance examination.

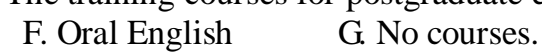

3. What ability do you want to approve yourself most?
A. Oral English
B. Listening comprehension
C. Reading comprehension. D. Writing. E. Translation

4. What kind of job do you like to hunt?
A. Stat-owned enterprise
B. overseas-funded enterprise
C. Joint venture
D. a private enterprise
E. Government
F. Self employed

5. Which area would you like to work in?
A. The Pearl River area
B. The Yangtse Rive area
D. The Northeast Part of China.
E. The central plain area
F. The Southwestern Part of China.
G. The Western part of China.
H. The Northwestern part of China.

6. Which kind of place do you like to work in China?
A. big cities
b. medium-sized cities
C. small cities
D. towns E. villages

Thank you vey much for having filled in this form of questionnaire. Best wishes to you for a successful career!

\section{ACKNOWLEDGEMENT}

I'd like to take this opportunity to thank my former student, Wang Xiao, who has helped me in the whole course of the investigation. Without her help, this thesis would not have been possible.

\section{REFERENCES}

[1] Chang, Xin, Kang Tinghu \& Wang Pei. (2005). The influence of cognitive and emotional factors on college students in the process of English learning. The Science of Psychology 3. 2-15.

[2] Gao, Yihong. (2003). Social psychology of the Chinese college students in their English Studies. Beijing: Foreign Language Teaching and Education Press.

[3] Huang, Hongan \& Wen Weiping. (2005). A case study of the motive factors in the English studies for non-English majors. Foreign Language Teaching Abroad 3. 17-23.

[4] Liu, Runqing \& Dai Manchun. (2003). A research on the developing policy and reform on foreign language teaching in Chinese universities. Beijing: Foreign Language Teaching and Education Press.

[5] Ma, Daoshan. (2005). Should CET be cancelled? Yu Xiaodan(ed.) On foreign language research and teaching. Changchun: Jilin University Press.254-259.

[6] Ren, Yonggang. (2005). Medical English education after the reform on CET. Yu Xiaodan(ed.) On foreign language research and teaching. Changchun: Jilin University Press.260-265.

[7] Tang, Wenli. (2005). Analyses and investigation on the effect of motive factors on speaking. Foreign Language Teaching 2. 23-31.

[8] Tang, Xiongying. (2005). CET and College English course evaluation. Foreign Language Teaching 2. 42-47.

[9] Wang, Zhengyuan. (2005). Counter-effect of English tests. Foreign Language Teaching 1. 11-16.

[10] China Higher Education Social Psychology Compiler Team. (2003). Social psychology. Tianjin: Nankai University Press.

Daoshan Ma, male, is a professor of the School of Foreign Languages, Tianjin Polytechnic University. His research interest includes syntax and comparative linguistics between English and Chinese. His major publications are: "Reflections on the Types of Natural Languages from the Perspective of Wh-movement" and "The Syntactic Evidence on the Chinese Interrogative Particle Ne". 